eISSN : 2580-3042

pISSN : 1979-0694

\title{
SISTEM INFORMASI INVENTARIS BARANG MENGGUNAKAN BAHASA PEMROGRAMAN PHP PADA SMAN 1 DUMAI
}

\author{
Amat Sofiyan ${ }^{1}$, Sularno $^{2}$, Fina Yuliana ${ }^{3}$ \\ ${ }^{1,2,3}$ Sekolah Tinggi Manajemen Informatika dan Komputer (STMIK) DUMAI \\ ${ }^{1,2,3}$ Jalan Utama Karya Bukit Batrem, Dumai, Kode Pos 28811 \\ e-mail : amatsofiyan90@gmail.com ${ }^{1}$
}

\begin{abstract}
ABSTRAK
Inventaris merupakan kegiatan pencatatan dan pendaftaran barang inventaris/hak milik. Barang milik negara merupakan bagian dari kekayaan negara yang terdiri dari satuan-satuan tertentu yang dapat dihitung. SMAN 1 Dumai merupakan salah satu sekolah menengah atas dan sebagai sekolah favorit di kota Dumai. Pengelolaan dan penyimpanan data inventaris barang pada SMAN 1 Dumai saat ini dilakukan menggunakan Microsoft Excel 2007. Namun sistem ini masih mengalami kekurangan, yaitu pembuatan data inventaris barang masih sederhana. Hal ini menyebabkan proses kerja yang membutuhkan waktu lama terutama saat melakukan pencarian data dan dapat terjadi redudansi data. Dengan demikian peneliti memberi solusi dengan membuat sistem informasi inventaris barang menggunakan bahasa pemrograman PHP, yang mana bahasa pemrograman ini mudah digunakan dan user friendly serta menggunakan data inventaris barang SMAN 1 Dumai sebagai database. Pada sistem inventaris ini menyediakan beberapa fitur yang dapat digunakan oleh pengguna, diantaranya input data sumber dana, input data barang, input data ruangan, input data penanggung jawab, input data gudang, KIR (Kartu Inventaris Ruang), nomor registrasi barang, laporan inventaris (per bulan, per periode, per tahun), laporan barang rusak (per bulan dan per periode) dan laporan prasarana.
\end{abstract}

Kata kunci : Barang, Informasi, Inventaris, PHP, Sistem

\section{ABSTRACT}

Inventory is an activity of recording and registering inventory items / property rights. State property is part of state wealth consisting of certain units that can be calculated. SMAN 1 Dumai is one of the high schools and as a favorite school in the city of Dumai. Management and storage of goods inventory data at SMAN 1 Dumai is currently carried out using Microsoft Excel 2007. However, this system is still experiencing shortages, namely making inventory data is still simple. This causes a work process that takes a long time, especially when searching for data and data redundancy can occur. Thus the researcher gave a solution by making an inventory information system using the PHP programming language, where the programming language is easy to use and user friendly and uses the inventory data of SMAN 1 Dumai as a database. In this inventory system provides several features that can be used by users, including input funding source data, input data items, input room data, responsible data input, warehouse data input, KIR (Space Inventory Card), item registration number, inventory report ( per month, per period, per year), reports of damaged items (per month and per period) and infrastructure reports.

Keywords: Goods, Information, Inventory, PHP, Systems

\section{PENDAHULUAN}

SMAN 1 Dumai didirikan sejak tahun 1975 di kota Dumai dan telah terakreditasi A. Hal ini membuat SMAN 1 Dumai memiliki banyak peminat terutama siswa-siswa yang ingin bersekolah di SMAN 1 Dumai. Karena banyak peminatnya, SMAN 1 Dumai selalu meningkatkan kinerja dan fasilitas khususnya dibagian pendataan inventaris barang.

Pendataan inventaris barang di SMAN 1 Dumai saat ini belum mempunyai sistem komputerisasi. Sehingga pegawai Tata Usaha di SMAN 1 Dumai mengalami berbagai kendala dalam menyajikan data inventaris tersebut. 
I N F O R M A I I A

Jurnal Informatika, Manajemen dan Komputer, Vol. 11 No. 1, Mei 2019

eISSN : 2580-3042

pISSN : 1979-0694

Kendalanya antara lain yaitu data inventaris yang ada di SMAN 1 Dumai dientrikan ke komputer menggunakan Microsoft Excel tanpa menggunakan database. Setelah data dientrikan, pegawai Tata Usaha mencetak data inventaris tersebut dan disimpan di lemari arsip.

Berdasarkan permasalahan tersebut maka dibutuhkan sebuah sistem komputerisasi yang dapat menghasilkan laporan yang efektif mengenai data inventaris barang seperti, mengetahui data inventaris barang, menyajikan laporan Kartu Inventaris Ruang (KIR), laporan nomor registrasi barang dengan cepat sehingga pengambilan keputusan dapat dilakukan dengan cepat.

\section{a. Sistem}

Menurut (Sutabri, 2012, p. 10) Sistem dapat diartikan sebagai suatu kumpulan atau himpunan dari unsur, komponen atau variabel yang terorganisir, saling berinteraksi, saling tergantung satu sama lain dan terpadu.

\section{b. Sistem Informasi}

Menurut (Andri Kristanto, 2003) sistem informasi adalah jaringan kerja dari prosedurprosedur yang saling berhubungan, berkumpul bersama-sama untuk melakukan kegiatan atau penyelesaian suatu sasaran tertentu (Sholikhin \& Riasti, 2013)

\section{c. Data}

Menurut (Tata Sutabri, 2012) Data adalah suatu istilah majemuk yang berarti fakta atau bagian dari fakta yang mengandung arti yang dihubungkan dengan kenyataan, simbol-simbol, gambar-gambar, angka-angka, huruf-huruf atau simbol yang menunjukkan suatu ide, objek, kondisi atau situasi dan lain-lain (Sihombing \& Khumaini, 2016)

\section{d. Inventaris}

Menurut (Budiono, 2005) inventaris merupakan daftar yang memuat semua barang milik kantor yang dipakai dalam melaksanakan tugas (Luthfi \& Riasti, 2011)

Menurut (Indrajit dan Djokopranoto, 2003) Sistem inventory adalah serangkaian kebijaksanaan dan pengendalian yang memonitor tingkat persediaan dan menentukan tingkat persediaan yang harus dijaga, kapan persediaan harus di isi, dan berapa besar pesanan yang harus dilakukan. Sistem ini bertujuan menetapkan dan menjamin tersedianya sumber daya yang tepat, dalam kuantitas yang tepat dan pada waktu yang tepat (Elisawati \& S, 2016)

\section{e. Flowchart}

Menurut (Mujono, 2012) flowchart adalah gambaran atau bagan yang memperlihatkan urutan dan hubungan antar proses beserta instruksinya (Prawiyanti \& Triyono, 2013)

\section{f. Context Diagram}

Menurut (Yakub, 2012, p. 156) Context diagram (top level) adalah bagian dari data flow diagram yang berfungsi memetakan model lingkungan, yang dipresentasikan dengan lingkaran tunggal yang mewakili keseluruhan sistem.

\section{g. Data Flow Diagram (DFD)}

Menurut (Deddy Kusbianto, 2010) DFD (Data Flow Diagram) sering digunakan untuk menggambarkan suatu sistem yang telah ada atau sistem baru yang akan dikembangkan secara logika tanpa mempertimbangkan lingkungan fisik dimana data tersebut mengalir atau lingkungan fisik dimana data tersebut akan disimpan (misalnya file kartu, microfile, harddisk, tape, disket dan lain sebagainya) (Cilla Mondev, Asparizal, \& Adrianto, 2017)

\section{h. Entity Relationship Diagram (ERD)}

Menurut (Deddy Kusbianto, 2010) ER (Entity-Relationship) merupakan model data tingkat tinggi yang popular untuk model data relasional. Model ini dengan sejumlah variasinya sering digunakan dalam desain konseptual dari aplikasi basis data. Dalam ER model, skema konseptual untuk suatu aplikasi basis data ditunjukkan dengan menggunakan notasi - notasi grafis yang disebut ERD (Cilla Mondev et al., 2017)

Tabel 1. Simbol-Simbol ERD

\begin{tabular}{|l|l|}
\hline Simbol & \multicolumn{1}{|c|}{ Keterangan } \\
\hline \multicolumn{1}{|c|}{$\begin{array}{l}\text { Entitas, yaitu kumpulan dari } \\
\text { objek dapat } \\
\text { diidentifikasikan secara unik }\end{array}$} \\
\hline $\begin{array}{l}\text { Relasi, yaitu hubungan yang } \\
\text { terjadi antara satu atau lebih } \\
\text { entitas. Jenis hubungan antara } \\
\text { lain; satu ke satu, satu ke } \\
\text { banyak dan banyak ke banyak }\end{array}$ \\
$\begin{array}{l}\text { Atribut, yaitu karakteristik dari } \\
\text { entity atau relasi yang } \\
\text { merupakan penjelasan detail } \\
\text { tentang entitas }\end{array}$ \\
\hline $\begin{array}{l}\text { Hubungan antara entity dengan } \\
\text { atributnya dan himpunan } \\
\text { entitas dengan himpunan } \\
\text { relasinya }\end{array}$ \\
\hline
\end{tabular}

Sumber : (Yakub, 2012, p. 60) 
I N F ORM A I K A

Jurnal Informatika, Manajemen dan Komputer, Vol. 11 No. 1, Mei 2019

eISSN : 2580-3042

pISSN : 1979-0694

\section{i. PHP}

Menurut (Bunafit, 2013, p. 153) PHP (PHP Hypertext Preprocessor) adalah bahasa program yang digunakan untuk membuat aplikasi berbasis web (website, blog atau aplikasi web). PHP termasuk bahasa program yang hanya bisa berjalan disisi server, atau sering disebut Side Server Language. Jadi, program yang dibuat dengan kode PHP tidak bisa berjalan kecuali dijalankan pada server web, tanpa adanya server web yang terus berjalan tidak akan bisa dijalankan.

\section{j. Database}

Menurut (Evayani \& Ulfah, 2016) Database adalah struktur penyimpanan data. Database juga merupakan kumpulan dari data yang saling berhubungan satu dengan yang lainnya, tersimpan diperangkat keras komputer dan digunakan perangkat lunak untuk memanipulasikan (Tugiarto, Pratiwi, Azkya, \& Widodo, 2018)

\section{k. MySQL}

MySQL (My Structured Query Language) adalah suatu perangkat lunak database relasi (Relational Database Management System atau RDMS). MySQL itu bekerja menggunakan bahasa basis data atau yang sering kita dengar dengan sebutan DBMS (Database Management System). Data Language ini terbagi dua macam, yaitu (MT \& Poerwanta, 2013, pp. 2-3):

a. DDL (Data Definition Language), yaitu perintah yang digunakan untuk pendefinisian suatu struktur data. Misalnya menciptakan database, field dan sebagainya.

b. DML (Database Manipulation Language), yaitu perintah untuk proses manipulasi data, misalnya create, read, update, delete (CRUD).

c. SQL (Structure Query Language), adalah bahasa yang digunakan untuk berkomunikasi antara pemakai dan komputer.

\section{I. ХАМРP}

Menurut (Andi Offset, 2014) XAMPP merupakan dari singkatan dari X (empat sistem operasi apapun), Apache, MySQL, PHP, dan Perl. XAMPP adalah tool yang menyediakan paket perangkat lunak dalam satu buah paket. Dalam paket XAMPP sudah terdapat Apache (web server), MySQL (database), PHP (server side scripting), Perl, FTP server, PhpMyAdmin dan berbagai pustaka bantu lainnya (Sandra, Pratiwi, \& Radillah, 2017)

\section{METODOLOGI PENELITIAN}

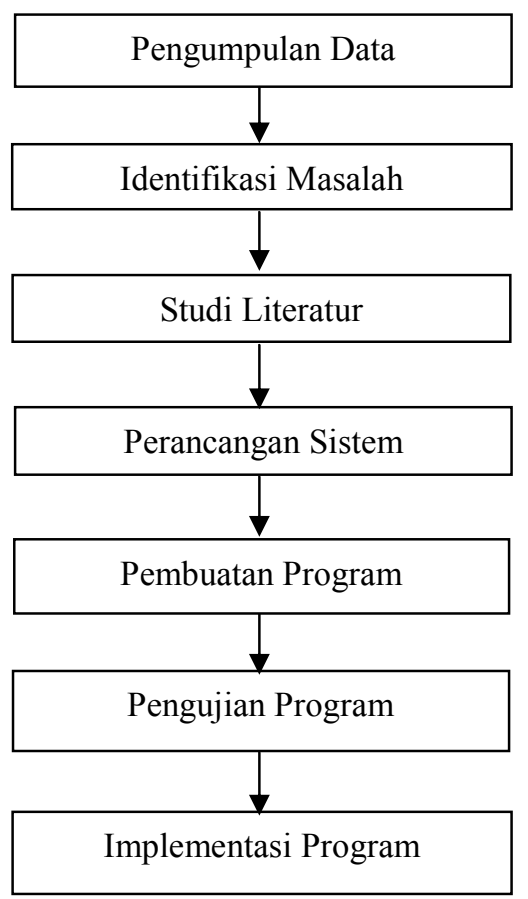

Gambar 1. Kerangka Kerja

Pembahasan dan penyelesaian penelitian ini dilakukan dengan mengikuti kerangka kerja berikut ini :

1. Teknik Pengumpulan Data

Tahap pertama yang dilakukan adalah pengumpulan data dengan teknik wawancara dan observasi.

a. Wawancara yaitu dengan melakukan wawancara dengan pegawai / staf yang bekerja pada tata usaha SMAN 1 Dumai, dalam upaya mendapatkan data yang diperlukan.

b. Observasi yaitu dengan melakukan pengamatan langsung terhadap sistem inventaris di SMAN 1 Dumai.

2. Identifikasi Masalah

Permasalahan utama dalam penelitian ini adalah Pengolahan data inventaris barang masih dilakukan dengan Microsoft Excel.

3. Studi Literatur

Pada penelitian ini dilakukan pencarian data dengan membaca dan mempelajari berbagai buku-buku mengenai komputer, internet serta pengetahuan yang berhubungan dengan masalah yang akan diteliti yaitu pengolahan data inventaris barang.

4. Perancangan Sistem

Beberapa perancangan program yang akan dibuat pada tahap ini yaitu: ERD (Entity Relationship Diagram), Context Diagram, 
I N F ORM A I K A

Jurnal Informatika, Manajemen dan Komputer, Vol. 11 No. 1, Mei 2019

eISSN : 2580-3042

pISSN : 1979-0694

Flowchart, DFD (Data Flow Diagram), Aliran Sistem Informasi (ASI) Lama dan Baru, Perancangan output dan input dan Perancangan file.

5. Pembuatan Program

Sistem yang dibangun dengan menggunakan bahasa pemrograman PHP dengan Database MySQL berdasarkan perancangan sistem yang telah dirancang.

6. Uji Coba Program

Uji coba program dilakukan dengan menginputkan beberapa record data untuk memastikan bahwa program yang telah dirancang layak untuk diimplementasikan.

7. Implementasi Program

Pada tahap ini dilakukan pengimplementasian program untuk mendapatkan hasil yang sesuai dengan yang diharapkan.

\section{HASIL DAN PEMBAHASAN}

a. Analisis Sistem Informasi (ASI) Yang Berjalan

Berikut ini merupakan keterangan dari Gambar 2, tentang aliran sistem informasi data barang inventaris yang berjalan pada SMAN 1 Dumai :

1. Tata Usaha mencatat Data Barang dan membuat Laporan Data Barang sebanyak 3 rangkap. 1 rangkap untuk diarsipkan, 1 rangkap untuk Penanggung Jawab dan 1 rangkap untuk Kepala Sekolah.

2. Penanggung Jawab memberikan Data Barang Rusak ke Tata Usaha, lalu Tata Usaha mencatat Data Barang Rusak tersebut dan membuat Laporan Barang Rusak sebanyak 3 rangkap. 1 rangkap untuk diarsipkan, 1 rangkap untuk Bendahara Barang dan 1 rangkap untuk Kepala Sekolah.

3. Tata Usaha membuat Laporan Inventaris Barang sebanyak 4 rangkap. Lalu Tata Usaha menyerahkan Laporan tersebut ke Penanggung Jawab. Setelah disetujui Penanggung Jawab, Laporan tersebut diserahkan ke Kepala Sekolah.

4. Setelah disetujui Kepala Sekolah dan diarsipkan 1 rangkap, Kepala Sekolah menyerahkan kembali laporan tersebut ke Tata Usaha. Tata Usaha mengarsipkan 1 rangkap. Lalu Tata Usaha menyerahkan Laporan tersebut ke Bendahara Barang dan Penanggung Jawab untuk diarsipkan.

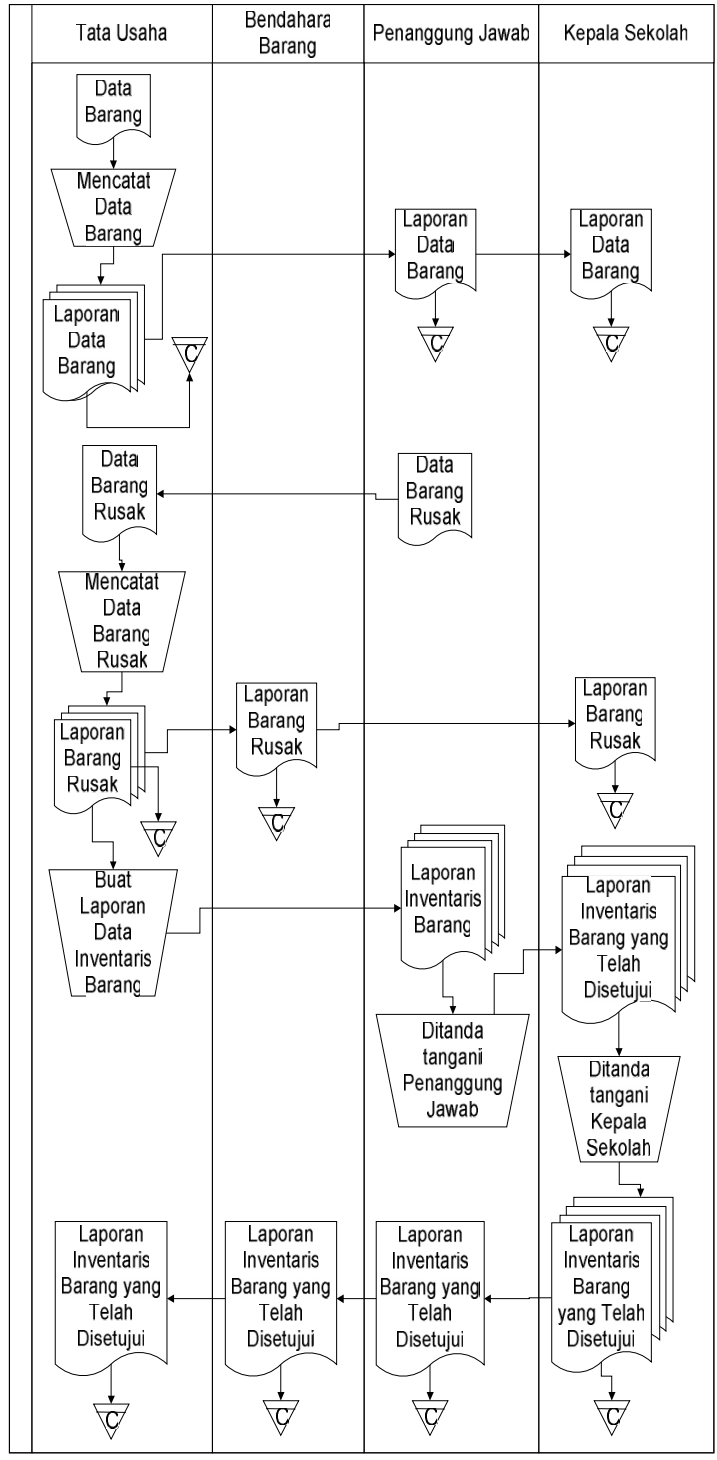

Gambar 2. Aliran Sistem Informasi (ASI) yang Berjalan

\section{b. Analisis Sistem Informasi (ASI) Yang Baru}

Berikut ini merupakan keterangan dari Gambar 3, tentang aliran sistem informasi data barang inventaris yang baru pada SMAN 1 Dumai :

1. Penanggung Jawab memberikan Data Barang Rusak ke Tata Usaha.

2. Tata Usaha memasukkan Data Barang dan Data Barang Rusak ke sistem. dan mencetak Laporan Barang Rusak sebanyak 3 rangkap. 1 rangkap diarsipkan Tata Usaha, 1 rangkap diarsipkan Bendahara Barang dan 1 rangkap diarsipkan Kepala Sekolah. 
I N F ORM A I K A

Jurnal Informatika, Manajemen dan Komputer, Vol. 11 No. 1, Mei 2019

eISSN : 2580-3042

pISSN : 1979-0694

3. Tata Usaha mencetak nomor registrasi barang sebanyak 2 rangkap. 1 rangkap untuk ditempel di barang-barang inventaris dan 1 rangkap lagi diarsipkan Kepala Sekolah.

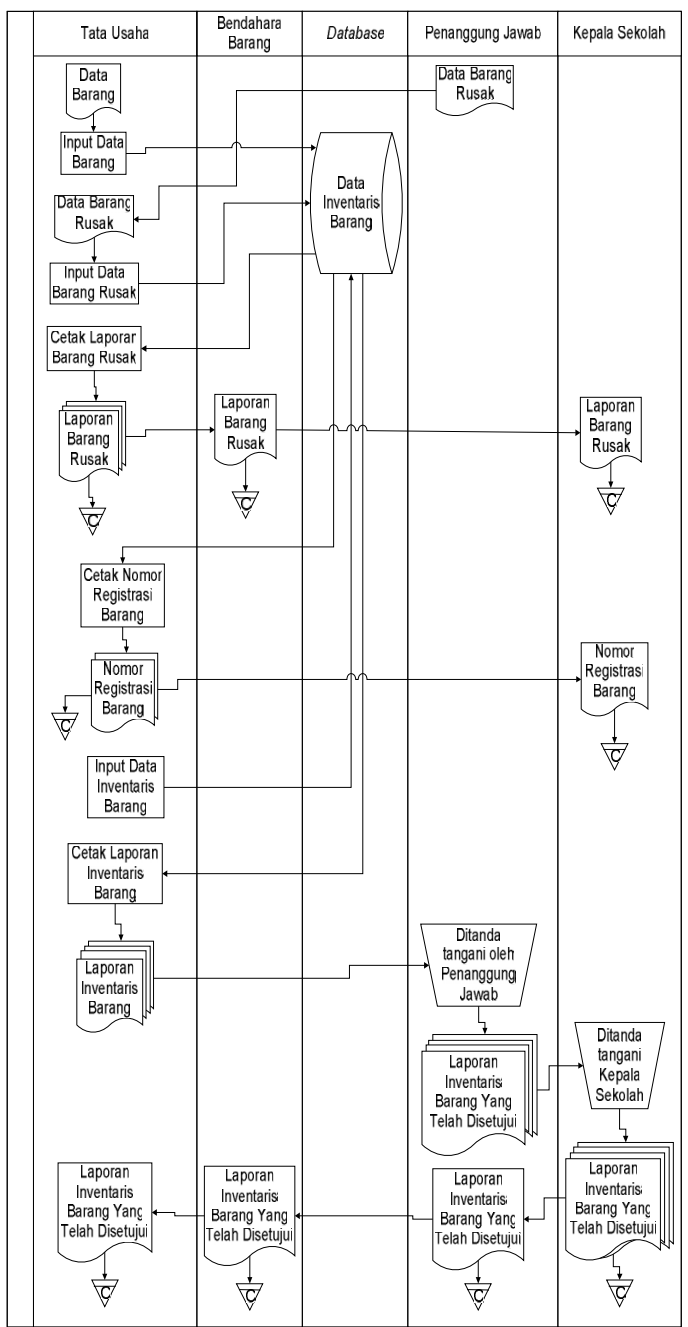

Gambar 3. Aliran Sistem Informasi (ASI) yang Baru

4. Tata Usaha memasukkan data inventaris barang ke sistem, lalu Tata Usaha mencetak laporan data inventaris barang sebanyak 4 rangkap. Tata Usaha menyerahkan laporan tersebut ke Penanggung Jawab dan ditandatangani. Lalu Penanggung Jawab menyerahkan laporan tersebut ke Kepala Sekolah dan ditandatangani.

5. Setelah laporannya ditandatangani, 1 rangkap diarsipkan Kepala Sekolah, 1 rangkap diarsipkan Penanggung Jawab, 1 rangkap diarsipkan Bendahara Barang dan 1 rangkap diarsipkan Tata Usaha.

\section{c. Context Diagram}

Adapun context diagram pada penelitian ini dapat dilihat pada gambar 4. Pada bagian context diagram terdapat 4 external entity yaitu Tata Usaha, Bendahara Barang, Penanggung Jawab dan Kepala Sekolah.

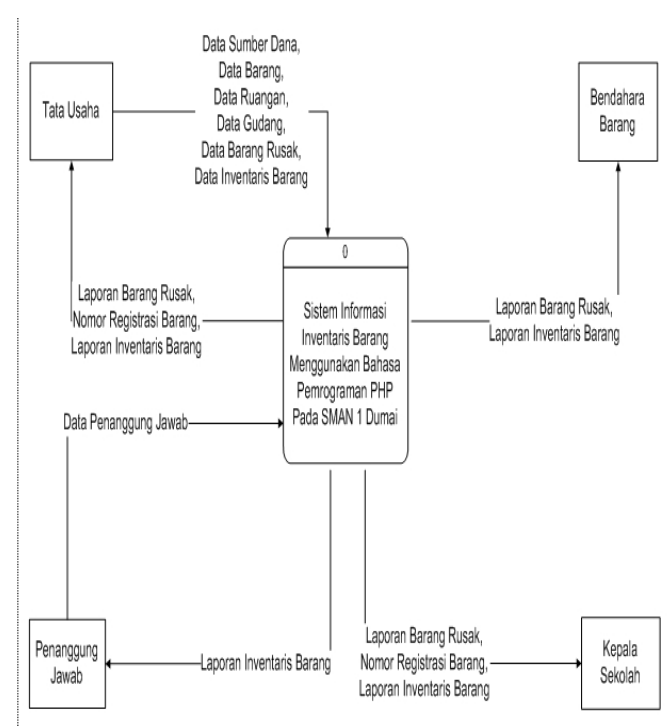

Gambar 4. Context Diagram

\section{d. Data Flow Diagram (DFD)}

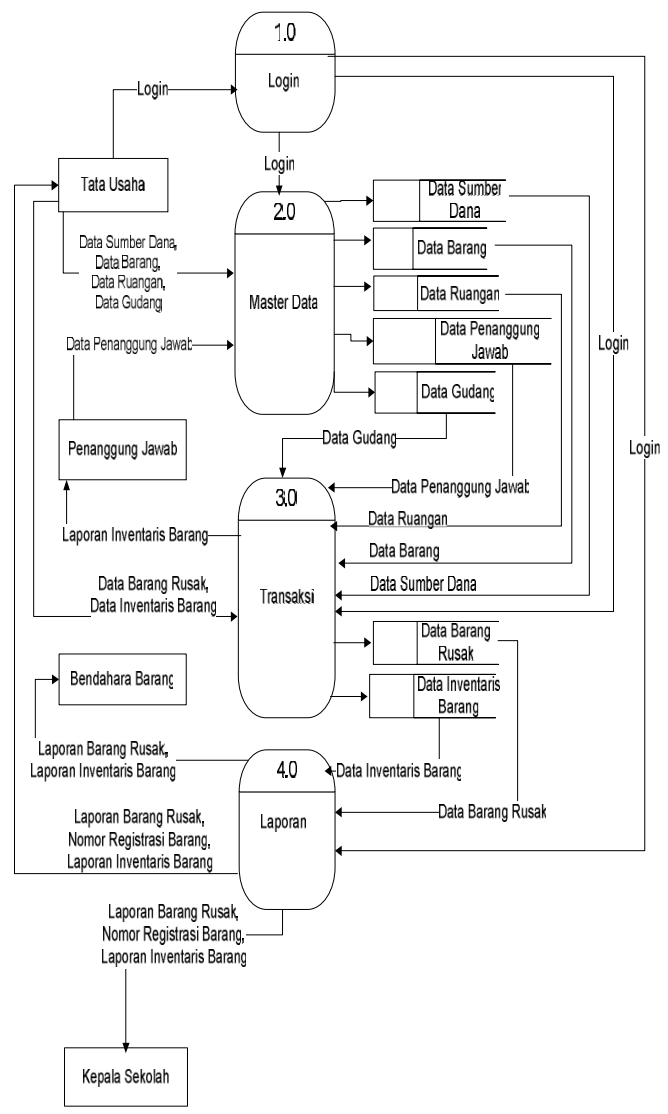

Gambar 5. Data Flow Diagram 
I N F ORM A I K A

Jurnal Informatika, Manajemen dan Komputer, Vol. 11 No. 1, Mei 2019

eISSN : 2580-3042

pISSN : 1979-0694

\section{e. Implementasi Sistem \\ Form Login}

Jika koneksi sukses atau terhubung ke server maka akan muncul form login aplikasi yang berfungsi sebagai keamanan aplikasi. Form login hanya mengizinkan user tertentu yang bisa mengakses sistem. User yang diizinkan hanya Tata Usaha. Cara menggunakan form login yaitu dengan memasukkan nama pengguna dan password. Jika telah di isi dengan benar, maka program aplikasi terbuka. Dapat dilihat pada Gambar 6.

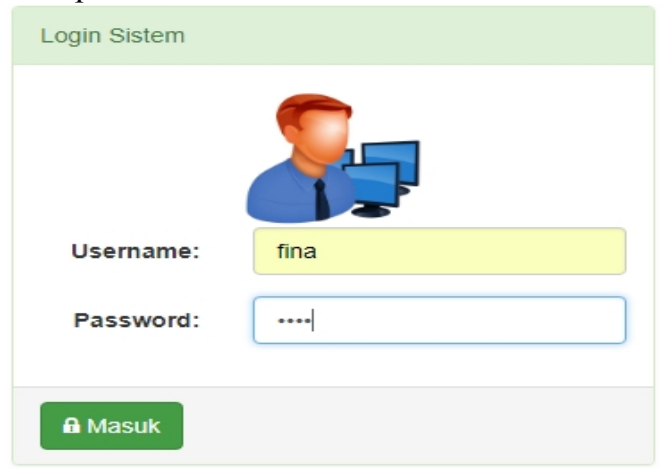

Gambar 6. Form Login

\section{Form Beranda}

Form Beranda merupakan tampilan menu utama yang berisi profil SMA Negeri 1 Dumai. Pada bagian atas terdapat Menu Utama yang terdiri dari Beranda, Data Master, Transaksi, Laporan dan Akun.

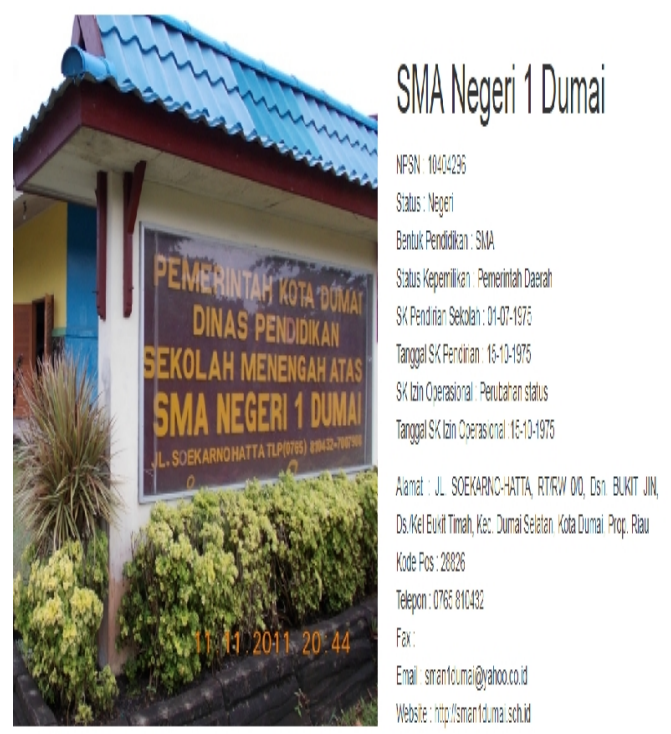

Gambar 7. Form Beranda

\section{Form Sumber Dana}

Menu utama yang kedua yaitu menu data master. Saat kursor diarahkan ke menu data master, otomatis akan muncul 5 sub menu yang

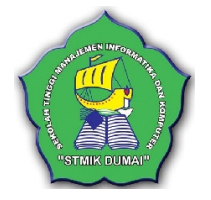

terdiri dari sumber dana, barang, ruangan, penanggung jawab dan gudang. Berikut ini adalah form sumber dana (Gambar 8). Dihalaman ini juga dilengkapi dengan tombol tambah data untuk menambah data sumber dana yang baru. Selain itu, pada halaman ini juga dilengkapi tombol ubah atau edit untuk mengubah data yang sudah diinput lalu diganti dengan data yang baru, tombol hapus untuk menghapus data yang sudah diinput dan kolom search atau cari untuk mencari data yang sudah diinputkan.

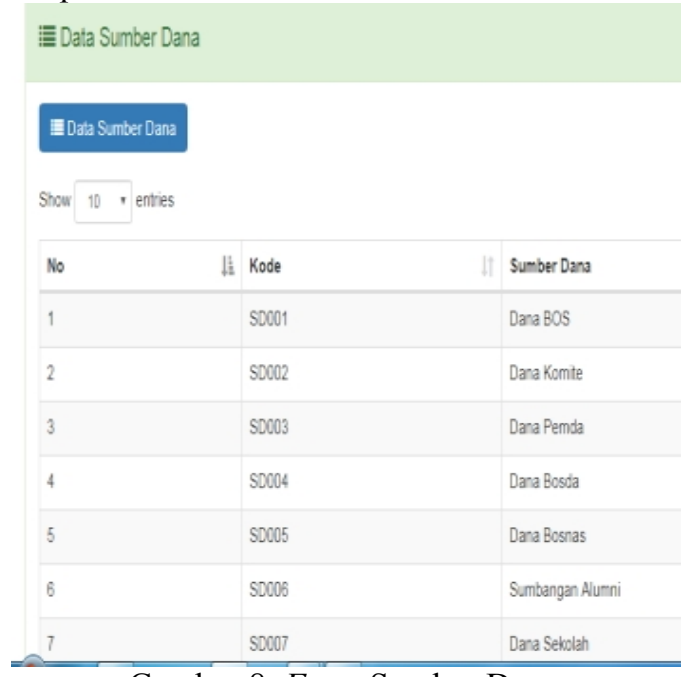

Gambar 8. Form Sumber Dana

\section{Form Data Barang}

Sub menu yang kedua dari data master yaitu data barang. Berikut ini adalah form data barang (Gambar 9). Dihalaman ini juga dilengkapi dengan tombol tambah barang untuk menambah data barang yang baru. Selain itu, pada halaman ini juga dilengkapi tombol import data barang dari excel untuk menambah data barang yang dari Microsoft Excel dan kolom search atau cari untuk mencari data yang sudah diinputkan.

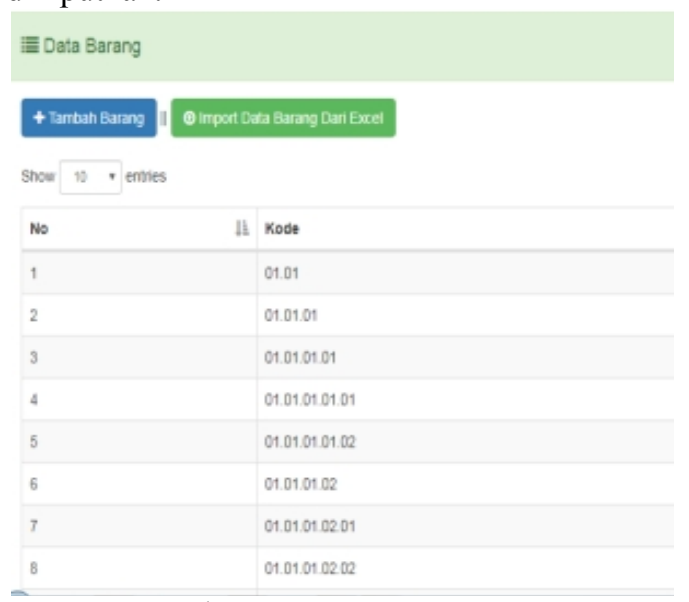

Gambar 9. Form Data Barang 
I N F ORM A I K A

Jurnal Informatika, Manajemen dan Komputer, Vol. 11 No. 1, Mei 2019

eISSN : 2580-3042

pISSN : 1979-0694

\section{Form Input Data Barang}

Input untuk data barang pada aplikasi ini ada 2 jenis yaitu dengan cara pertama klik pada tombol tambah barang (tombol warna biru) kemudian isi datanya berupa kode barang dan nama barang lalu klik tombol simpan. Jika tidak, klik tombol batal.

\section{+ Tambah Data Barang \\ Kode Barang \\ 11.11.11.11.11. \\ Nama Barang

Meja Kayu

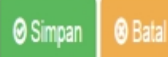 \\ Gambar 10. Form Input Data Barang}

\section{Form Input Data Barang Menggunakan Microsoft Excel \\ Input untuk data barang pada aplikasi ini} yang dengan cara kedua yaitu menggunakan Microsoft Excel. Caranya dengan klik pada tombol import data barang dari excel (tombol warna hijau). Lalu tampilan akan menjadi seperti Gambar 11. Kemudian klik tombol Choose File, pilih file data barang yang akan di import. Lalu centang pada kosongkan tabel barang terlebih dahulu dan klik tombol Import Data.

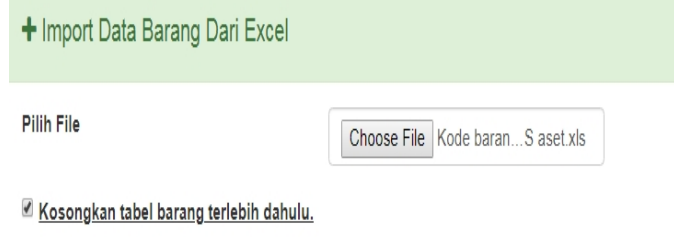

\section{Olmport Data 0 Batit}

Gambar 11. Form Input Data Barang Menggunakan Ms. Excel

\section{Form Data Penanggung Jawab}

Sub menu yang ketiga dari data master yaitu data penanggung jawab. Berikut ini adalah form data penanggung jawab (Gambar 12). Dihalaman ini juga dilengkapi dengan tombol tambah data untuk menambah data penanggung jawab yang baru. Selain itu, pada halaman ini juga dilengkapi tombol edit atau ubah data untuk mengubah data yang sudah diinput lalu diganti dengan data yang baru, tombol hapus untuk menghapus data yang sudah diinput dan kolom search atau cari untuk mencari data yang sudah diinputkan.

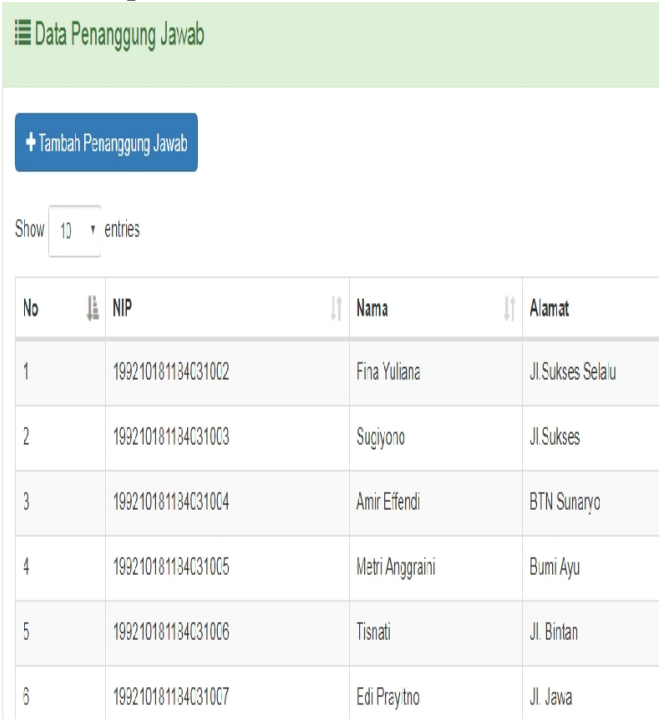

Gambar 12. Form Data Penanggung Jawab

\section{Form Data Ruangan}

Sub menu yang keempat dari data master yaitu data ruangan. Berikut ini adalah form data ruangan (Gambar 13). Dihalaman ini juga dilengkapi dengan tombol tambah data untuk menambah data ruangan yang baru. Selain itu, pada halaman ini juga dilengkapi tombol edit atau ubah data untuk mengubah data yang sudah diinput lalu diganti dengan data yang baru, tombol hapus untuk menghapus data yang sudah diinput dan kolom search atau cari untuk mencari data yang sudah diinputkan. Antara data ruangan dengan data penanggung jawab memiliki hubungan atau berelasi. Oleh karena itu, data penanggung jawab harus diisi terlebih dahulu agar nama penanggung jawab nya bisa digunakan saat memasukkan data baru di data ruangan.

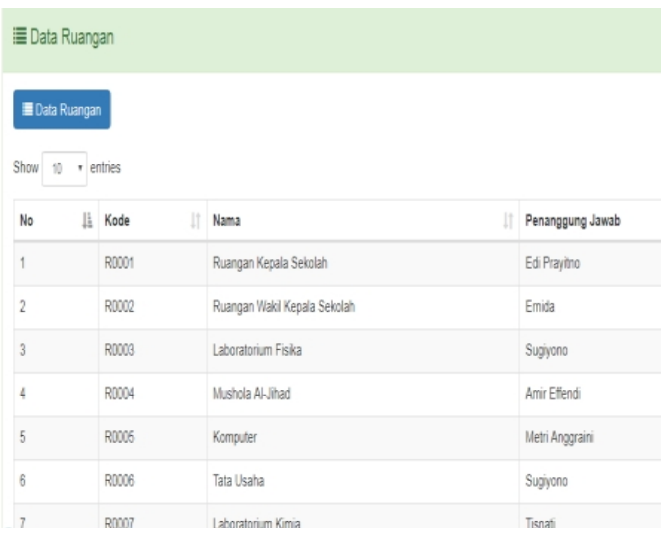

Gambar 13. Form Data Ruangan 
I N F ORM A I K A

Jurnal Informatika, Manajemen dan Komputer, Vol. 11 No. 1, Mei 2019

eISSN : 2580-3042

pISSN : 1979-0694

\section{Form Data Gudang}

Sub menu yang kelima dari data master yaitu data gudang. Berikut ini adalah form data gudang (Gambar 14). Dihalaman ini juga dilengkapi dengan tombol tambah data untuk menambah data yang baru. Selain itu, pada halaman ini juga dilengkapi tombol edit atau ubah data untuk mengubah data yang sudah diinput lalu diganti dengan data yang baru, tombol hapus untuk menghapus data yang sudah diinput, tombol view atau lihat data untuk melihat detail data yang telah diinput dan kolom search atau cari untuk mencari data yang sudah diinputkan. Antara data gudang, data sumber dana dan data barang memiliki hubungan atau berelasi. Oleh karena itu, data barang dan data sumber dana harus diisi terlebih dahulu agar nama sumber dana dan kode barang nya bisa digunakan saat memasukkan data baru di data gudang.

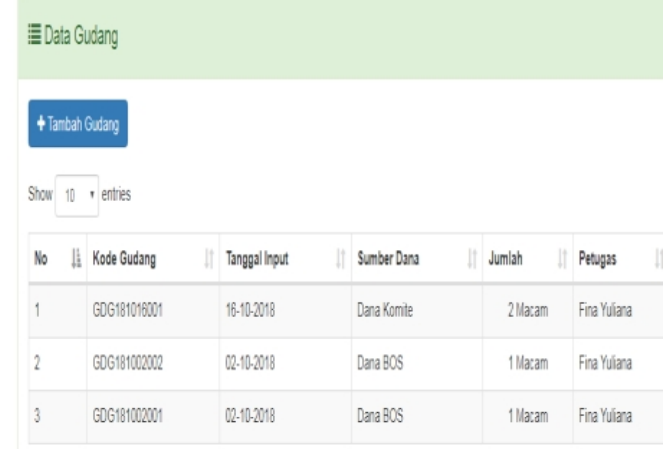

Gambar 14. Form Data Gudang

\section{Form Transaksi Data Inventaris}

Kembali ke menu beranda, menu utama ketiga yaitu transaksi. Sub menu nya adalah inventaris dan barang rusak. Berikut ini adalah form data inventaris (Gambar 15). Dihalaman ini juga dilengkapi dengan tombol tambah data untuk menambah data yang baru. Selain itu, pada halaman ini juga dilengkapi tombol edit atau ubah data untuk mengubah data yang sudah diinput lalu diganti dengan data yang baru, tombol hapus untuk menghapus data yang sudah diinput, tombol view atau lihat data untuk melihat detail data yang telah diinput, tombol cetak untuk mencetak nomor registrasi barang yang akan ditempel di barang-barang inventaris aset dan kolom search atau cari untuk mencari data yang sudah diinputkan.
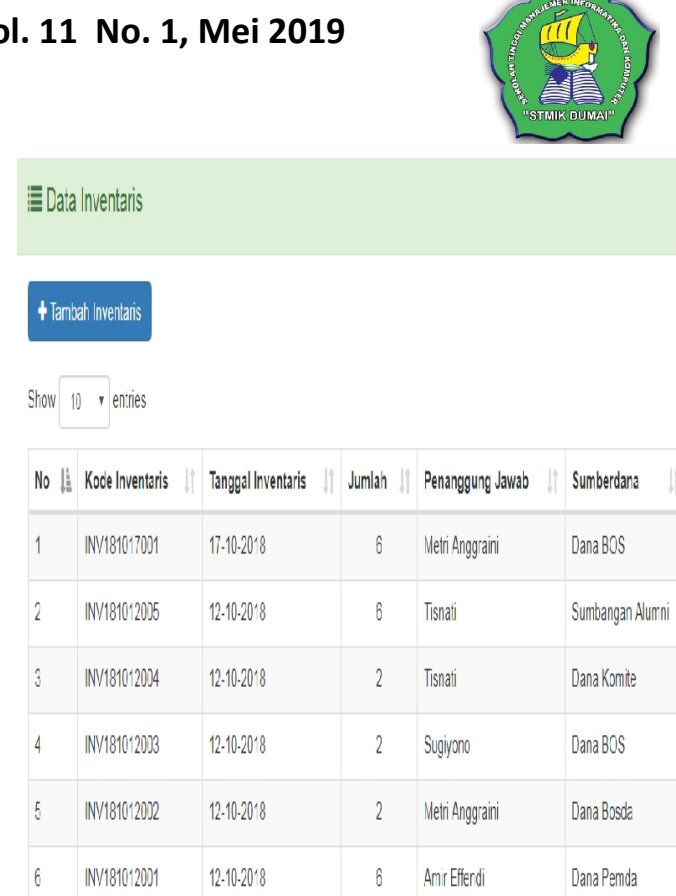

Gambar 15. Form Data Inventaris

\section{Form Transaksi Data Barang Rusak}

Sub menu kedua dari data transaksi adalah barang rusak. Berikut ini adalah form data barang rusak (Gambar 16). Dihalaman ini juga dilengkapi dengan tombol tambah data untuk menambah data yang baru. Selain itu, pada halaman ini juga dilengkapi tombol edit atau ubah data untuk mengubah data yang sudah diinput lalu diganti dengan data yang baru, tombol hapus untuk menghapus data yang sudah diinput, tombol view atau lihat data untuk melihat detail data yang telah diinput, dan kolom search atau cari untuk mencari data yang sudah diinputkan.

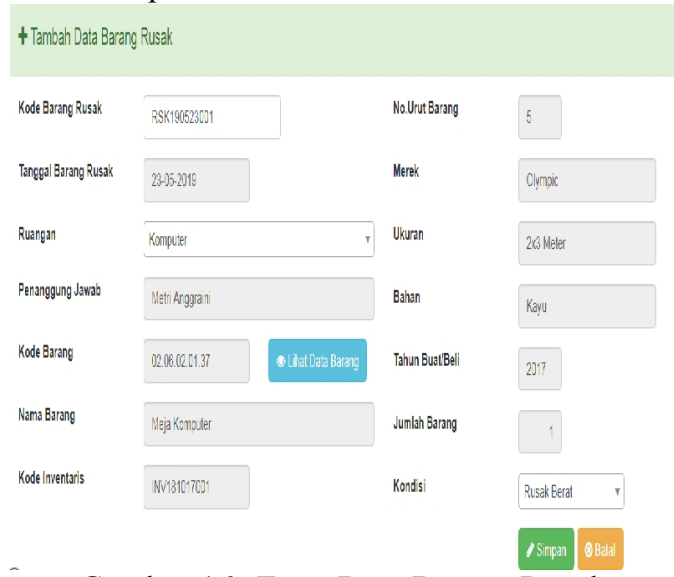

Gambar 16. Form Data Barang Rusak

\section{Laporan Kartu Inventaris Ruang (KIR)}

Adapun tampilan laporan kartu inventaris ruang adalah sebagai berikut : 
I N F O R M A I K A

Jurnal Informatika, Manajemen dan Komputer, Vol. 11 No. 1, Mei 2019

eISSN : 2580-3042

pISSN : 1979-0694

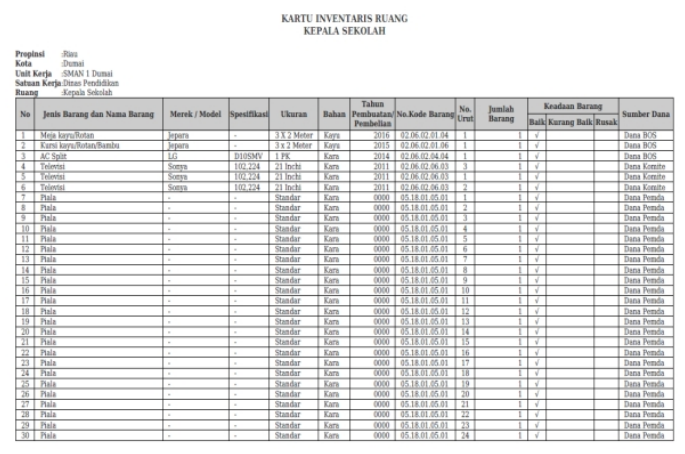

Gambar 17. Laporan KIR

Laporan Inventaris Bulanan

Adapun tampilan laporan inventaris bulanan adalah sebagai berikut :

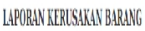

Periode Eulan Oither Taun 2018

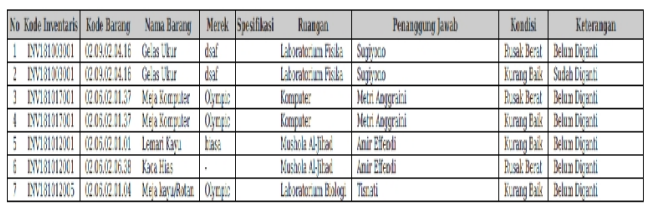

Gambar 18. Laporan Inventaris Bulanan

\section{Laporan Inventaris Tahunan}

Adapun tampilan laporan inventaris tahunan adalah sebagai berikut :

$$
\begin{aligned}
& \text { LAPORA INTENIARIS RLANG } \\
& \text { IATA LSHAB }
\end{aligned}
$$

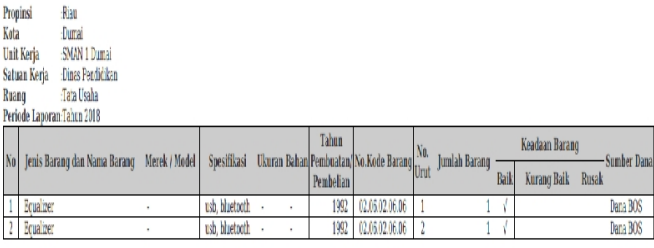

Gambar 19. Laporan Inventaris Tahunan

\section{Nomor Registrasi Barang}

Adapun tampilan nomor registrasi barang adalah sebagai berikut :

\begin{tabular}{|l|ll|}
\hline suar1 & Kode Barang & $:$ 02.06.02.06.05 \\
Nama Jenis Barang & $:$ Amplifier(Panasonic) \\
Reg & $: 01$ \\
\hline & Digunakan & $:$ Ruangan Wakil Kepala Sekolah \\
\hline
\end{tabular}

Gambar 20. Nomor Registrasi Barang

\section{Laporan Kerusakan Barang}

Adapun tampilan laporan kerusakan barang adalah sebagai berikut :

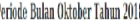

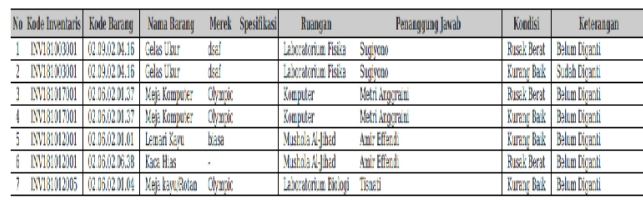

Gambar 21. Laporan Kerusakan Barang

Laporan Pergantian Barang Rusak

Adapun tampilan laporan pergantian barang rusak adalah sebagai berikut :

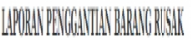

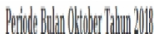

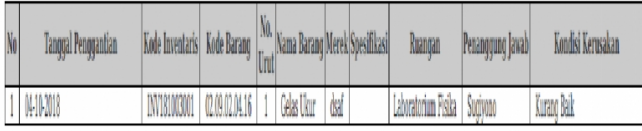

Gambar 22. Laporan Pergantian Barang Rusak

\section{Laporan Prasarana}

Adapun tampilan laporan prasarana adalah sebagai berikut :

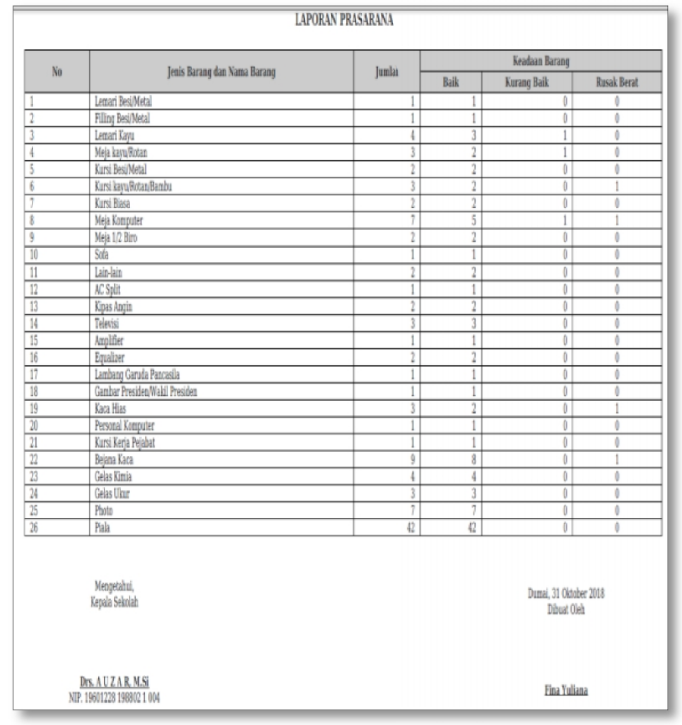

Gambar 23. Laporan Prasarana

\section{KESIMPULAN}

Berdasarkan hasil pembahasan yang telah diuraikan, dapat diambil kesimpulan :

1. Dengan adanya sistem informasi inventaris barang menggunakan bahasa pemrograman PHP serta mendukung untuk pembuatan laporan, maka dapat dihasilkan suatu laporan dengan cepat dikarenakan 
I N F ORM T I K A

Jurnal Informatika, Manajemen dan Komputer, Vol. 11 No. 1, Mei 2019

eISSN : 2580-3042

pISSN : 1979-0694

datanya tersusun dan tersimpan dalam media penyimpanan komputer.

2. Dengan adanya sistem ini, pengolahan data barang serta transaksi data inventaris dan barang rusak pada SMAN 1 Dumai seperti penambahan, penghapusan, perubahan, pencarian dan pembuatan laporan lebih cepat dan akurat.

3. Kartu Inventaris Barang (KIR) dan Nomor registrasi barang yang akan ditempel di setiap barang inventaris dapat dicetak (print) melalui sistem ini, serta adanya variasi bentuk laporan, yaitu laporan per periode, laporan bulanan dan laporan tahunan.

\section{REFERENSI}

Bunafit, N. (2013). Dasar Pemrograman Web PHP - MySQL Dengan Dreamweaver (Pertama). Yogyakarta: Gava Media.

Cilla Mondev, A., Asparizal, \& Adrianto, S. (2017). Komputerisasi Barang Inventaris Pada Kantor Lingkungan Hidup Kota Dumai. Informatika, Manajemen Dan Komputer, 9(1), 1-9. Retrieved from http://www.ejournal.stmikdumai.ac.id/ind ex.php/path/article/view/57

Elisawati, \& S, M. H. R. R. (2016). Sistem Inventory Suku Cadang Sepeda Motor Untuk Menghitung Estimasi Stok Menggunakan Metode EOQ (Studi Kasus: PT . SUZUKI RJC OMBAK ). Informatika, Manajemen Dan Komputer, $8(2), 1-7$.

Luthfi, H. W., \& Riasti, B. K. (2011). Sistem Informasi Perawatan Dan Inventaris Laboratorium Pada SMK Negeri 1 Rembang Berbasis Web, 3(4), 1-9.

MT, Y., \& Poerwanta, R. (2013). Perancangan Sistem Inventory Spare Parts Mobil Pada $\mathrm{Cv}$. Auto Parts Toyota Berbasis Aplikasi Java. Jurnal TEKNOIF, 1, 1-5. Retrieved from https://ejournal.itp.ac.id/index.php/tinfor matika/article/view/139/138

Prawiyanti, A. A., \& Triyono, R. A. (2013). Perancangan Sistem Informasi Inventaris Program Studi Teknik Informatika Universitas Surakarta. Seminar Riset Unggulan Nasional Informatika Dan Komputer FTI UNSA, 2(1), 43-53. Retrieved from seruniid.unsa.ac.id

Sandra, Y., Pratiwi, F., \& Radillah, T. (2017).

Sistem Pencatatan Surat Masuk Dan Surat Keluar Menggunakan Pemrograman PHP, $9(1), 59-69$.

Sholikhin, A., \& Riasti, B. K. (2013). Pembangunan Sistem Informasi Inventarisasi Sekolah Pada Dinas Pendidikan Kabupaten Rembang Berbasis Web Akhmad Sholikhin, Berliana Kusuma Riasti. Indonesian Journal on Networking and Security (IJSN) - Ijsn, 2(2), 50-57. https://doi.org/10.1248/cpb.22.1487

Sihombing, J., \& Khumaini, H. (2016). Sistem Informasi Penjualan Game Pc Berbasis Web Pada Toko Oe Games Menggunakan Php. Jurnal Informatika, Manajemen Dan Komputer, 8 No. 2(1), 43-48.

Sutabri, T. (2012). Konsep Sistem Informasi. (I. Nastiti, Ed.) (Pertama). Yogyakarta: Andi Offset.

Tugiarto, A., Pratiwi, F., Azkya, A., \& Widodo, P. P. (2018). Pengolahan Data Pasien Rawat Jalan Puskesmas Bumi Ayu Kota Dumai, 10(2), 13-20.

Yakub. (2012). Pengantar Sistem Informasi (Pertama). Yogyakarta: Graha Ilmu. 